\title{
A Five Circles Model for Designing Mathematics Teacher Education Programs and Framing Common Standards for Educators
}

\author{
Yenealem Ayalew ${ }^{\mathrm{a}}$ \\ ${ }^{a}$ Addis Ababa University, Ethiopia
}

\begin{abstract}
Mathematics teacher education is a complex, interdisciplinary enterprise requiring knowledge of teaching and learning as well as knowledge of mathematics. The Education and Training policy of Ethiopia reminds Teacher training institutions to gear their programmes towards the appropriate educational level for which they train teachers. Candidates of an inservice mathematics teacher training program have double identities: school teacher and university student. Yet, there is no vivid standard for Mathematics Teacher Educators in the country. Three basic questions were raised and answered by this study. What are the possible sources of stakeholders' roles in training mathematics teachers? What would be the roles of mathematics teacher educators? What minimum competencies are expected of mathematics educators? A qualitative content analysis research approach was followed. By analyzing data collected from 25 in-service teachers, consulting official documents and reviewing related literatures, I have developed a framework of standards that illustrates an Educator's roles, competencies and challenges as composite functions of practicing teachers' experience and students' expectation. This work will have impact on the theory of preparing Mathematics Teacher Educators and brings a new model of developing a Mathematics teacher education program.
\end{abstract}

KEYWORDS

Mathematics, Teacher Educator, standards
ARTICLE HISTORY

Received 22 December 2016

Revised 16 March 2017

Accepted 18 March 2017

\section{Introduction}

Nowadays, Mathematics teaching is more challenging and thus a teacher program is more demanding. Teachers might gain mathematics knowledge from textbooks and a variety of people like supervisors, students, colleagues, etc (Kessel, 2009). A formal Mathematics teacher education helps trainees to be more knowledgeable, adaptable, judicious, insightful, resourceful, reflective and competent professionals (Zaslavsky \& Sullivan, 2011) so that the way students

CORRESPONDENCE Yenealem Ayalew $\square$ yenealem2025@yahoo.com

(c) 2017 Yenealem Ayalew.

Open Access terms of the Creative Commons Attribution 4.0 International License

(http://creativecommons.org/licenses/by/4.0/) apply. The license permits unrestricted use, distribution, and

reproduction in any medium, on the condition that users give exact credit to the original author(s) and the source, provide a link to the Creative Commons license, and indicate if they made any changes. 
are taught in classrooms would be for better learning outcomes. These demand serious reflection on how to support frontline educators in developing their teaching skills. Thus, the challenge for mathematics teacher educators will be to find ways to describe the scope and depth of knowledge. Since a teacher educator is part of a learning system (Roesen, 2011), it demands serious reflection on how to support frontline educators in developing their teaching skills (Barter, Buchele, Reuter-Herzer \& Selka, 2011).

There are some good efforts in popularizing Mathematics Teacher Educator as a subject (Jaworski \& Woods, 2008). The United States of America based Association of Mathematics Teacher Educators having mathematics educators, mathematicians, teacher leaders, school district mathematics experts, and others as members has dedicated a website and journal of Mathematics Teacher Educator. However, as to my information, different groups of academicians are claiming that they are the sole determinants of the training of teachers. The concerning body, Ministry of Education (MoE), had developed standards for school teacher, supervisors and principals. However, there is no standard for educators. Each university assigns the 'appropriate' instructor for a course. Particularly, for teacher education, the instructor is expected to pursue a Higher Diploma in Teaching. The following Trainers' profiles have been used as guidelines for recruiting an educator.

- Capable teachers who have relevant academic qualification and teaching experience

- Graduates of Higher Diploma in teaching and who are licensed as Trainers (MoE, 2007).

The Blue Print (MoE, 2007) did not explicitly noted indicated the standards of such Trainers. Though a Mathematics Teacher educator has key role in the overall enterprise of training mathematics teachers, it seems that the preparation of educators had not get emphasis. As an example, let me quote one experience. I pursued my first degree in Pedagogical Science and Mathematics majors from Bahir Dar University 12 years ago. The goal of the program was to produce human power for Teachers' Training colleges and institutes. So, the track shaped me as a mathematics teacher educator. I continued my further education. Yet, I am questioning what is expected of me as an educator. I have been delivering different undergraduate level courses for summer in-service mathematics teachers at Dire Dawa and Addis Ababa universities in Ethiopia. I had trainees who criticize their instructors' capabilities and competencies.

When a training of mathematics teachers is thought, the intention is to equip them exercise their role of teaching effectively. That calls for identifying roles to be played, setting the competencies of the educators and overcoming challenges in the teacher education program. The ultimate goal of training teachers is to maximize their students' success. Yet, there is a need to think beyond setting criterions for who will train best teachers. Having delivered different courses for in-service mathematics teachers, I used to think of what should be important to consider as a Mathematics Teacher Educator. Explicitly, the following research questions are forwarded to be answered via this study.

- What are the possible sources of stakeholders' roles in training mathematics teachers? 
- What would be the roles of mathematics teacher educators?

-What minimum competencies are expected of mathematics educators?

The main purpose of this study is therefore to develop common standards for Mathematics Teacher Educators in the Ethiopian context.

\section{Material and Methods}

Developing a framework would be the strategy of the study. This in turn demands coding and categorizing of concepts from the data. So, the study is guided by a qualitative approach of which content analysis is the very useful way to obtain information that describes the issue or topic.

My primary sources of data are my 34 trainees of the course Subject Area Mathematics Methods I of the Postgraduate Diploma Program in Teaching (PGDT) in 2015. The candidates were in-service mathematics Teachers having 1 to 3 experiences teaching at primary and secondary schools in Addis Ababa and the surrounding areas. I started class by asking them reflect on their experiences and challenges while teaching mathematics. The intentions were to support the planned learning outcomes of the course with their experience and expectations. Writing about a personal best (role model) teacher was the first activity of their portfolio. Open questions were forwarded to all of them. The candidates disclosed their own best teachers among from their primary, secondary, preparatory secondary, or university level teachers of all courses they had taken. As a Mathematics Teacher educator, I need to understand such visions. As long as they are in the Teaching Profession, they might be aspired to be as their former best teachers did. So no matter what content I convey, I need to exhibit roles that address such expectations. Therefore, I have relied on my empirical data already collected from 25 candidates. Considering 25 out of 34 teacher students was based on their completed reports on the activity since all candidates did not organized their portfolio in the same fashion.

Another source of data was theoretical studies in formulating the standards. I have also looked in to an official document that states standards for school teachers in Ethiopia (MoE, 2012). I have also referred to different strategies for and principles of Mathematics Teacher Educators forwarded in the literature.

Then, the analysis of gathered data was made by coding and narrative discussion. In the course of analysis, I have learnt that there must be some model portraying the basic questions and steps to construct the roles, responsibilities and competencies of instructors of teachers. Finally, I forwarded a new five circles model for designing a mathematics teacher education program.

\section{Results and Discussion}

This section covers the presentation and discussion of data categorized in to three parts. The first sub-section is due to open-ended questions. The second part goes to the theoretical study of foundations of Mathematics Teacher Educators. The last sub-section reviews accessible official documents pertaining roles and competencies of Mathematics Teacher educators. 


\section{Model Teachers}

The next Table outlines the inspiring qualities of in-service mathematics teachers' own referred best Teachers. A Critical case is that only few university Mathematics instructors are mentioned as best or model teachers. On the other hand, 6 out of 17 model teachers were specialist of subject other than mathematics. This does mean that most of the Mathematics in-service Teachers might have studied the subject with no interest; or, the qualitative evaluation dominates the quantitative measure of a Teacher. My assumption for requesting trainees about their model teachers was to apply their imagination for professional endeavor. It was evident that qualities of best or role model teachers for my trainees were beyond the standards for Ethiopian school teachers. The main characteristics mentioned were: mastery of the subject matter, communication skill, classroom management skill, disposition and commitment for the teaching profession, having good personality traits, forming collaboration with and facilitating students work well, use of instructional materials \& aids, follow up students' progress, etc. Undoubtedly, teachers' interactions with their students are the main source of learning (Leikin \& Zazkis, 2011). All in all, the referred qualities can be labeled in to the six principles of mathematics education (NCTM, 2000). These are equity, curriculum, learning, teaching, assessment and technology.

Table 1. Postgraduate Diploma in Teaching Mathematics Candidate's Role Model Teachers

\begin{tabular}{|c|c|c|}
\hline Best Teacher & $\begin{array}{l}\text { Level \& Subject } \\
\text { taught }\end{array}$ & Qualities of the Best Teacher \\
\hline \multirow[t]{6}{*}{ Getasew } & 12, Chemistry & Knows the content; has communication skill \\
\hline & & Collaborates with all the learning community \\
\hline & & Is effective in classroom management \\
\hline & & Focuses on the educational needs of students \\
\hline & & Teaches students how to manage their own progress \\
\hline & & Creates suitable learning environment \\
\hline \multirow[t]{5}{*}{ Muluken } & 11-12, Biology & Always pushes students to do their best \\
\hline & & Makes learning interesting and creative \\
\hline & & Sets up and design the classroom; \\
\hline & & keeps the attention of students \\
\hline & & Organizes different optional activities for students \\
\hline \multirow[t]{4}{*}{ Mulugeta } & 11, Biology & Has good personality; uses teaching aids and materials \\
\hline & & Is effective in classroom management \\
\hline & & Wears Gown; \\
\hline & & creates awareness on students about the aim of the \\
\hline
\end{tabular}


subject

$\mathrm{X}$

$\mathrm{X}$

Zerihun

11, Physics

Fiseha

12, Civics

Meseret

Mezgebu

$\mathrm{X}$

$2^{\text {nd }}$ Year, Linear Algebra

10, Mathematics
Treats all students equally;

is knowledgeable and confident on the subject

Has rich experience in the field of physics

Is fluent speaker of English language in the teaching and learning process

Is punctual; is cheerful

Teaches clearly and in understandable way

Implements continues Assessment effectively

Leads student centered learning and teaching process

Is punctual; makes students satisfied with easy teaching style

Prepares many worksheets and exercises

Always ready to support students

Respects and motivates students

Is free from any type of discriminations

Has language skill

Is knowledgeable on the subject matter

Has good relationship with students

Has classroom and time management skills

Respects the teaching profession

Is intelligent;

uses teaching aids and materials

Starts class on time;

treats students properly;

implements the lesson, weekly and annual plans properly;

gives many worksheets and exercises for students;

wears dress properly; respects others and their ideas

Is keen to help students 


\begin{tabular}{lll}
\hline Abebe & Makes the class condition comfortable for all students \\
Science subjects & Enables students understand the concept of Mathematics \\
& Motivates \& encourages passive learners \\
& Influenced students to specialize in Mathematics \\
\hline
\end{tabular}

Table 2. Postgraduate Diploma in Teaching Mathematics Candidate's Role Model Teachers (Continued)

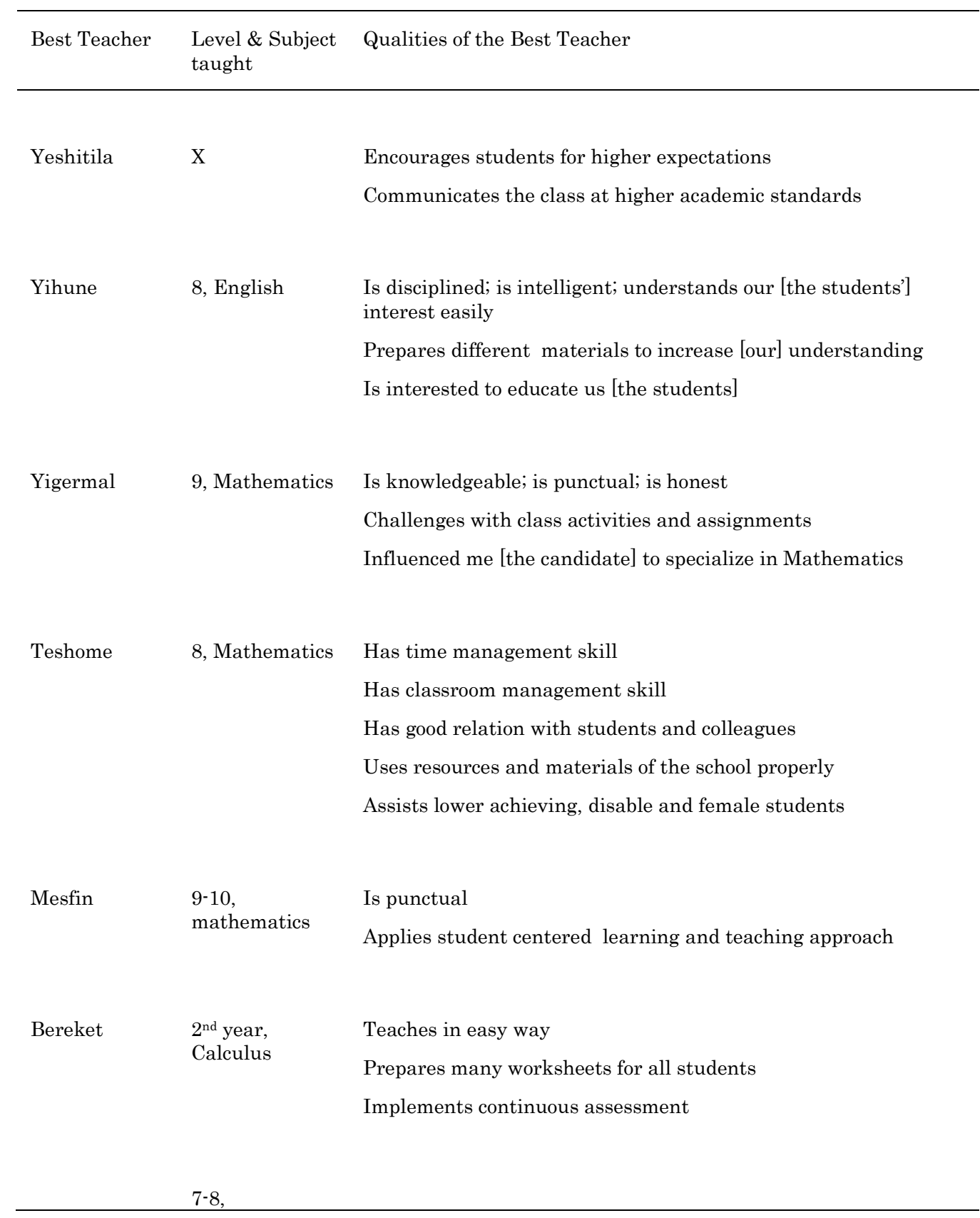




\begin{tabular}{|c|c|c|}
\hline \multirow[t]{3}{*}{ Wassie } & \multirow[t]{3}{*}{ mathematics } & Is knowledgeable beyond the subject matter \\
\hline & & Treats all students equally \\
\hline & & Is interested in teaching \\
\hline \multirow[t]{3}{*}{ Workaferahu } & \multirow[t]{3}{*}{ 7, Mathematics } & Uses teaching aids; is planned \\
\hline & & Knows and follows each student \\
\hline & & Has good personal behaiviour \\
\hline \multirow[t]{5}{*}{ Fasil } & \multirow[t]{5}{*}{$\mathrm{X}$} & Uses short and precise methods for students \\
\hline & & Focuses on practical skill than theoretical knowledge \\
\hline & & Is punctual; creates good situations for students \\
\hline & & Directs students to be critical and able to reason out \\
\hline & & Checks students work \\
\hline \multirow[t]{2}{*}{ Argata } & \multirow[t]{2}{*}{$\mathrm{X}$} & Is committed to his work; respects his work \\
\hline & & Advices and Encourages students \\
\hline \multirow[t]{3}{*}{ Shewakena } & \multirow[t]{3}{*}{$\mathrm{X}$} & Makes the lesson interesting [enjoyable] \\
\hline & & Ensures the success of every student \\
\hline & & Has cooperative behaiviour; is committed \\
\hline \multirow[t]{2}{*}{ Tesfaye } & \multirow[t]{2}{*}{$\mathrm{X}$} & Respects time; is always happy; appreciates student's work \\
\hline & & Prepares worksheet \\
\hline \multirow[t]{2}{*}{ Olana } & \multirow[t]{2}{*}{$\mathrm{X}$} & Appreciates student's work \\
\hline & & Is wonderful teacher; understands the progress of students \\
\hline Eshetu & 6, Mathematics & $\begin{array}{l}\text { Anticipates the future of students; gives tutorials on regular } \\
\text { basis }\end{array}$ \\
\hline \multirow[t]{2}{*}{ Eyerus } & \multirow{2}{*}{$\begin{array}{l}2^{\text {nd }} \text { year, } \\
\text { Linear algebra }\end{array}$} & Delivers the course in understandable way \\
\hline & & Gives tutorials according to academic level of students \\
\hline
\end{tabular}




\section{The Need for Mathematics Teacher Educators}

The ultimate goal of a teacher training is to prepare teachers render their role in equipping students with intended competencies. Hence, an educator or a stakeholder of teacher's professional development will contribute in the realization of such expectations of the pre-service or in-service trainees. The Mathematics Teachers' competencies useful for teaching (Zaslavsky, 2008; Zaslavsky \& Sullivan, 2011) will create corresponding challenges for Teacher Educators. Training teachers would urge educators for holding a flexibility skill. The teacher-educator may engage teachers in different activities. Therefore, the demands on mathematics teacher educators are heavy, in terms of their knowledge-base, personal traits, and responsibilities (Zaslavsky, 2008).

\section{Foundations for Roles and Competencies Mathematics Teacher Educators}

When we talk about the teaching and learning of Mathematics, we usually refer to the classroom event. It is more demanding that teaching and learning process as it "happens within a culturally situated context" (Foote, 2010, P.1). That is in line with viewing the construction of mathematical knowledge in social context. Be it a teacher dominated or student centered class, both the teacher and students play their own role in the attainment of assumed intentions. In student centered approach, teachers put students' current knowledge and interests at the centre of their instructional decision making. They provide students with opportunities to work both independently and collaboratively to make sense of ideas. According to Glenda \& Margaret (2009), mathematics learning experiences could enable students to build on their existing proficiencies, interests, and experiences.

Planning of student's learning starts with the thinking of goals and objectives of mathematics. We might be interested in balancing of the knowledge, skill and attitude aspects. But, there are many options for designing what and how students learn. I am in favor of Sullivan's (2011) five strands of desirable mathematical actions for students: conceptual understanding, procedural fluency, strategic competence, adaptive reasoning, and productive disposition. According to Foote (2010), teaching for understanding could advance all students towards academic excellence. Glenda and Margaret (2009) suggested strategies for adjusting teachers' instruction to meet students' learning: (a) connecting learning to what students are thinking, (b) using students' misconceptions and errors as building blocks, and (c) appropriate challenge. However, Cowan (2006) argued that learning occurs in an unstructured, discovery-based situation. Students learn from more knowledgeable others (peers, teachers, parents) by enquiry, and at a pace and time that suits them.

My perception of successful learning and effective teaching come from our perspectives on the two interconnected terminologies. Cowan (2006) explained Teaching as it must be planned to be continuous, and it must be enjoyed to be sustained for the rest of one's life. By the pursuit of effective teaching, supervisors might develop checklist for assessing a mathematics teacher's performance. Even teachers themselves might be concerned how much efficient in their job. It is appropriate to raise Cowan's (2006) two basis questions on the 
matter. How can mathematics be taught effectively? What are the key issues in mathematics teaching today?

So, we need to have a broader view of teaching mathematics. It demands to be concerned for National Curriculum for mathematics, classroom management and working with pupils, misconceptions in mathematics, using mathematics resources, and assessment. Sullivan's (2011) six key principles for effective teaching of mathematics: (1) Articulating goals, (2) Making connections, (3) Fostering engagement, (4) Differentiating challenges, (5) Structuring lessons and (6) Promoting fluency and transfer. More specifically, Glenda and Margaret (2009) forwarded the next ten strategies for teaching Mathematics effectively.

1) Caring classroom communities that are focused on mathematical goals help develop students' mathematical identities and proficiencies.

2) Provide students with opportunities to work both independently and collaboratively to make sense of ideas.

3) Plan mathematics learning experiences that enable students to build on their existing proficiencies, interests, and experiences.

4) Understand that the tasks and examples they select influence how students come to view, develop, use, and make sense of mathematics.

5) Support students in creating connections between different ways of solving problems, between mathematical representations and topics, and between mathematics and everyday experiences.

6) Use a range of assessment practices to make students' thinking visible and to support students' learning.

7) Facilitate classroom dialogue that is focused on mathematical argumentation.

8) Shape mathematical language by modelling appropriate terms and communicating their meaning in ways that students understand.

9) Carefully select tools and representations to provide support for students' thinking.

10) Develop and use sound knowledge as a basis for initiating learning and responding to the mathematical needs of all their students.

Therefore, a teacher needs to have knowledge of subject matter and skill of classroom management. They facilitate classroom dialogue, encourage their students to explain and justify their solutions, and foster students' use and understanding of the terminology. Educators have long claimed that good teaching is the key to higher student achievement, as well as to other positive student outcomes, such as moral values and tolerance (Carnoy et al, 2009). Effective teachers develop and use sound knowledge as a basis for initiating learning and responding to the mathematical needs of all their students. They can critically evaluate students' processes, solutions, and understanding and give appropriate and helpful feedback. They can see the potential in the tasks they set; this, in turn, contributes to sound instructional decision making (Glenda \& Margaret, 2009).

The nature of mathematics teaching affects the nature and outcomes of student learning. Teachers are assigned a key role because only they can change the way mathematics will be taught (Roesken, 2011). There is consistency between how teachers go about their work and their views of learning (Harlen, 
1993). There are some who provide range of activities for students; some other keep their whole time in class so that students share teachers attention; still others encourage groups work together. These highlight the huge responsibility teachers have for their students' mathematical well-being (Glenda \& Margaret, 2009). The role of the teacher is beyond what he (she) takes as a teacher. It also includes the role he (she) allows for students and the way in which he (she) uses resources (Harlen, 1993).

In Ethiopian context, school teachers' demonstration of determined standards will occur within their specific teaching context at their stages of expertise and reflect the learning requirements of the students they teach (MoE, 2012). The seven standards for school teachers are:

1) Know students and how they learn

2) Know the content and how they teach it

3) Plan for and implement effective teaching and learning

4) Create and maintain supportive and safe learning environment

5) Assess, provide feedback and report on student learning

6) Engage in professional learning

7) Engage professionally with Colleagues, parents/care givers and the community

Teachers' competency refers to the level of performance required for the successful achievement of school expectation. The competencies expected from a Mathematics Teacher can be leading goals in Education program (Zaslavsky, 2008; Zaslavsky \& Sullivan, 2011). Teachers use their knowledge to make the multiple decisions about tasks, classroom resources, talk, and actions that feed into or arise out of the learning process (Glenda and Margaret, 2009). To teach mathematical content effectively, teachers need a grounded understanding of students as learners to make instructional decisions that strengthen conceptual understanding.

\section{Promoted Roles and Competencies of Mathematics Teacher Educators}

According to Simon (2008), a Mathematics teacher educator is required to: (1) articulate models of teaching; (2) identify the key pedagogical concepts; (3) understand teachers' conceptions; and (4) promote teachers' development and important pedagogical concepts. A general approach was given by The Association of Teacher Educators in USA (ATE) categorized in to the following nine standards (http://www.ate1.org/pubs/Home.cfm). These are: Teaching, Cultural Competence, Scholarship, Professional Development, Program Development, Collaboration, Public Advocacy, Teacher Education profession, and Vision. However, scholarship and professional development seem to overlap. The last Standard is also part of a professional development. Similarly, in 2010, the Association of Teacher Educators in Europe endorsed the following areas of expertise or knowledge required by Teacher Educators:

- the pedagogy of educating teachers

- educational studies

- (practice-based) research

- schools as institutions

- professionalism

- the discipline 
- the discipline as school subject

- the discipline didactics

- general didactics

- school-based education

- new skills (e.g. digital competences ...)

(http://www.atee1.org/uploads/isl_pla_teacher_educators_report_final.pdf)

It may not logical to employ the standards suggested in one case for other contexts. However, for a Teacher Educator, very broad knowledge base and several personal qualities are required. While allowing teachers to review key theoretical perspectives, the educators need to have high level meta-cognitive and mentoring skills to facilitate and foster opportunities for student teachers. A Teacher Educator requires a familiarity with a wide range of available tools and must be aware of barriers associated with diversity. Therefore, the teacher Educator needs to have positive dispositions.

\section{Designing a Mathematics Teacher Education Program}

Teachers and quality of their teaching would have paramount impact on the overall quality of education. A Mathematics Teacher Education program should contain goals, content standards, a common vision, a curriculum framework, and instructional materials. The next figure illustrates the basic questions that should be considered in planning and running of a mathematics teacher education program. There are three basic steps there. The first one is a matter of thinking and planning. The targets are teachers who need to pursue the training; thus, the learning of teachers is the leading mission. The learning of teachers is basically held with the interaction of their students (Leikin \& Zazkis, 2010) in the classroom. Therefore, the development of teacher education has to consider the learning of students that the teachers would serve. 


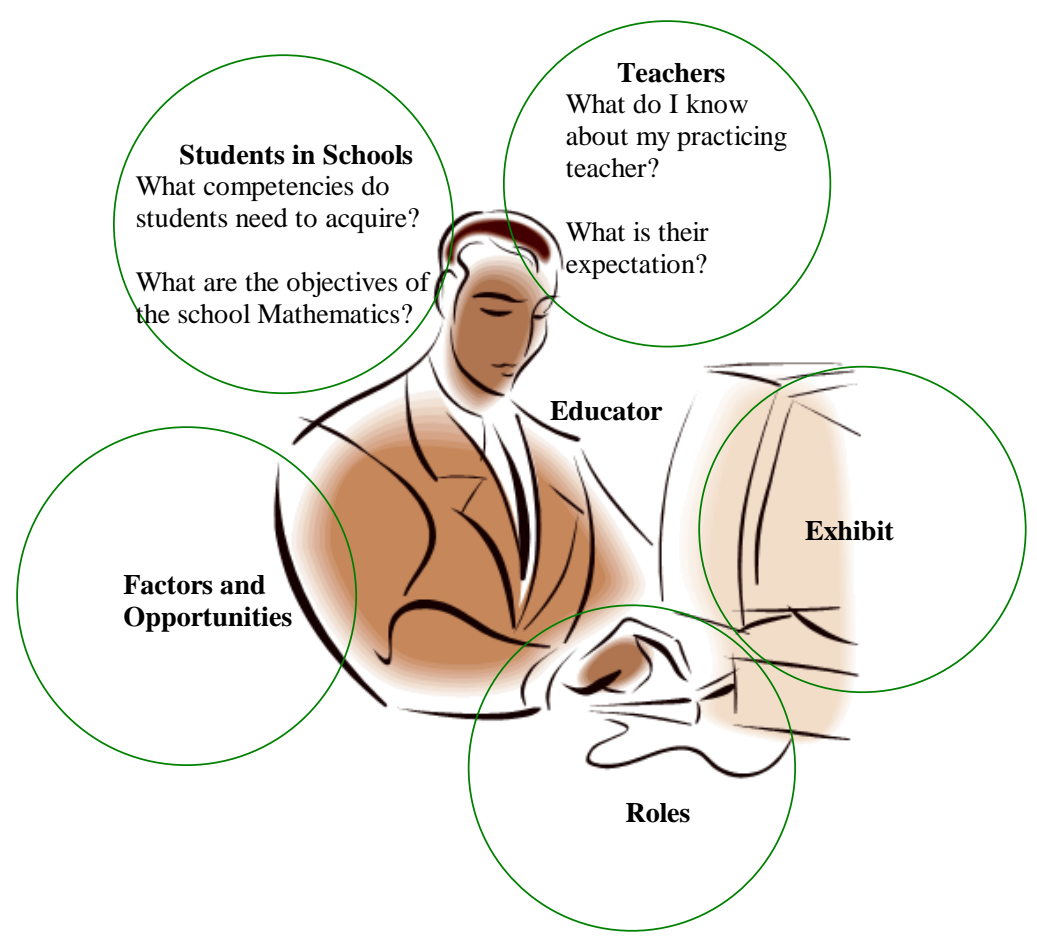

Figure 1. Sources of Roles and Competencies of a Mathematics Teacher Educator

The Figure depicts the how of planning of a mathematics teacher education program. I call this framework the 5-circles model. Educators for Mathematics teachers (pre-service or in-service) should put themselves in to the situation by which the assumed program is to be happen. The first step will be thinking about teachers to be trained, their students and related issues like inputs, resources, context, etc. Since the teacher could decide what constitutes appropriate professional development (Roesen, 2011), a Mathematics Teacher Educator should be aware of the required Mathematical knowledge to produce competent and motivated professionals. She or he needs to understand the experiences, challenges of teachers and to be aware of the school environment and expectations of the school Mathematics education program.

The following step would be planning phase which includes designing of a curriculum, and developing of action plan for the program. In doing so, one body could not be the sole determining stakeholder of the program; it demands to involve teachers, curriculum experts, mathematics specialists, mathematics educators, supervisors, etc. Thus, planning has consider the factors and existing opportunities of a teacher education program. Dalelo, T/Mariam \& Kassaye (2008) identified eight key barriers in ensuring quality in teacher education and the teaching profession at large. These are: insufficient teacher remuneration, shortage of high quality applicants, poor subject matter knowledge, poor pedagogical preparations, disconnecting theory and practice, poor command of medium of instruction, limited professional preparation of teacher educators, and failure to bring about favorable attitude towards the profession. Many of the problems could have resulted in to the emergent of different reforms in 
secondary teacher preparation (Semela, 2014). Since 2011, the Post Graduate Diploma in Teaching (PGDT) is under implementation. Shortage of appropriate mentors was mentioned as one problem in Kassa \& Amdemeskel (2013).

The planning phase would have focus points like: student's achievement in Mathematics, the mathematics curriculum, ensuring the quality of mathematics lessons, the nature and its content of teacher education program, etc. The curriculum might affect what will be taught and learned. The mathematics knowledge of primary and secondary school students is weak in many countries, an outcome that may be, in part, a product of this situation. Also of relevance here is the claim that educational reforms directly affecting the mathematics preparation of teachers and the curriculum they are expected to teach are frequently prompted by mandates deployed with little or no empirical basis supporting their effectiveness.

This would call for a collaborative work for the development of Mathematics teachers and ultimately maximizing quality students' learning. By the next Table, I proposed eight standards for qualifying Mathematics Teacher Educators. Those standards would inform the roles and competencies required. Their corresponding description is given too.

Table 3. Adapted Standards for Mathematics Teacher Educators in Ethiopia

\begin{tabular}{|c|c|c|}
\hline No & Standard & Description of the Standard \\
\hline \multirow[t]{5}{*}{1} & \multirow{5}{*}{$\begin{array}{l}\text { Personality and } \\
\text { Professional Ethics }\end{array}$} & Being a role model for teachers; Behaves as disciplined; \\
\hline & & Be punctual and honest; Time and classroom management skills \\
\hline & & Treats all students properly and equally; \\
\hline & & Is committed, planned and organized. \\
\hline & & Cheerful in front of teachers so that they can be attracted \\
\hline \multirow[t]{3}{*}{2} & \multirow{3}{*}{$\begin{array}{l}\text { Language and } \\
\text { Communication }\end{array}$} & Teaching proficiency; Language Skills (Leikin \& Zazkis, 2010); \\
\hline & & Teaches in easy way but keeping the standard; \\
\hline & & Makes learning interesting \\
\hline \multirow[t]{3}{*}{3} & School Mathematics & Be aware of the school mathematics curriculum; \\
\hline & Education & Imagine students that the teacher students would be able to serve; \\
\hline & & $\begin{array}{l}\text { Understand teachers' experiences in teaching, mathematical } \\
\text { knowledge gaps (or misconceptions) and challenges in their career. }\end{array}$ \\
\hline \multirow[t]{2}{*}{4} & Guidance and Support & $\begin{array}{l}\text { Create and maintain supportive and collegial relationship with } \\
\text { teacher students; }\end{array}$ \\
\hline & & $\begin{array}{l}\text { Establish a supportive culture for teachers pursuing their } \\
\text { professional development (Roesen, 2011); }\end{array}$ \\
\hline
\end{tabular}




\begin{tabular}{|c|c|c|}
\hline & & Acknowledge teacher beliefs and affect (Roesen, 2011); \\
\hline & & Creates good learning atmosphere and facilitate learning; \\
\hline & & Directs teachers to be critical thinkers; Appreciates teachers' work \\
\hline \multirow[t]{3}{*}{5} & $\begin{array}{l}\text { Assessment and } \\
\text { Feedback }\end{array}$ & $\begin{array}{l}\text { build discussion and critique into informal aspects of practice } \\
\text { (Gates, 2001) }\end{array}$ \\
\hline & & $\begin{array}{l}\text { Follow up and evaluate teachers' learning and professional } \\
\text { development; }\end{array}$ \\
\hline & & Implement continuous Assessment \\
\hline \multirow[t]{2}{*}{6} & $\begin{array}{l}\text { Partnership \& } \\
\text { Collaboration }\end{array}$ & $\begin{array}{l}\text { Enable teachers to develop a sense of ownership and partnership } \\
\text { (Roesen, 2011); interaction with colleagues (Leikin \& Zazkis, 2010); } \\
\text { instructors of other course that would be delivered for the target } \\
\text { teacher students; }\end{array}$ \\
\hline & & Involving and engaging teacher students \\
\hline \multirow[t]{6}{*}{7} & $\begin{array}{l}\text { Professional } \\
\text { Development }\end{array}$ & $\begin{array}{l}\text { Teacher educators need to be cautious and self-critical with respect } \\
\text { to their own understanding of professional development (Roesen, } \\
\text { 2011). }\end{array}$ \\
\hline & & Being knowledgeable beyond the required course content level \\
\hline & & $\begin{array}{l}\text { Engage in professional learning and development as a teacher and } \\
\text { educator; }\end{array}$ \\
\hline & & $\begin{array}{l}\text { Be an innovative professional by using or conducting research in } \\
\text { order to contribute in improving the quality of education. }\end{array}$ \\
\hline & & Publication as Evidence of documented professional growth \\
\hline & & Systematically reflect on own practice and learning; \\
\hline \multirow[t]{4}{*}{8} & Teacher Education & $\begin{array}{l}\text { Aware of the Mathematics relevant for training of Teachers and } \\
\text { how to teach it; }\end{array}$ \\
\hline & & $\begin{array}{l}\text { Plan and deliver the course by involving the teacher students and } \\
\text { incorporating current research and/or best practices; Aware of } \\
\text { innovative approaches sensitive to teachers' needs and their } \\
\text { conceptions (Roesen, 2011); Investigate theoretical and practical } \\
\text { problems in teaching, learning, and/or teacher education; }\end{array}$ \\
\hline & & $\begin{array}{l}\text { Ground practice in current policy and research related to teaching } \\
\text { and teacher education of Mathematics; }\end{array}$ \\
\hline & & $\begin{array}{l}\text { Responsible for offering courses that provide teachers with strong } \\
\text { exposure to appropriate content and that model the kinds of } \\
\text { pedagogical approaches appropriate for teaching that content } \\
\text { (CSMTP, 2001). }\end{array}$ \\
\hline
\end{tabular}

Then, implementation of the program follows. The instructors exhibit their plans. 


\section{Conclusion and Implication}

Teaching is a continuous quest for improved knowledge and improved practice (Brodie, 2010). Meaningful change in teaching takes time, imagination, courage, and honest reflection on what works and what does not. I realized that an instructor of a course for Mathematics Teachers would have to have best practices. The Educator's roles, competencies and challenges as composite functions of practicing teachers' experience and students' expectation. Based up on the initial data and theoretical studies presented earlier, I have forwarded the following areas of standards for a Mathematics Teacher Educator in Ethiopian context.

- Personality and Professional Ethics

- Language and Communication

- School Mathematics Education

- Guidance and Support

- Assessment and Feedback

- Partnership and Collaboration

- Professional Development

- Teacher Education

The above standards can be used for delivering courses to teachers of Mathematics teachers and evaluation of performance. Since the Mathematics Teacher Educators are not from the same field of specialization, it is difficult to write down the detailed certification criterions. The above eight points can be used to select and immerse the Educators. This Framework will have impact on valuing Mathematics Teacher Educators as specializing Professionals. The research output has brought the 5 -Circles model of developing a Mathematics teacher education program.

\section{Disclosure statement}

No potential conflict of interest was reported by the authors.

\section{Notes on contributors}

Yenealem Ayalew, PhD Candiate in Mathematics Education, Addis Ababa University, Ethiopia.

\section{References}

Barter, M., Buchele, U., Reuter-Herzer, M. \& Selka, R. (1989). Creative Tasks for Independence and Motivation, Berlin: Bundesinstitut.

Brodie, K. (2010). Teaching Mathematical Reasoning in Secondary School Classrooms. New York: Springer.

Brown, T. \& McNamara, O. (2005). New Teacher Identity and Regulative Government: The Discursive Formation of Primary Mathematics Teacher Education. New York: Springer.

Carnoy, M. et al (2009). Do Countries Paying Teachers Higher Relative Salaries Have Higher Student Mathematics Achievement? Amsterdam: International Association for the Evaluation of Educational Achievement (IEA).

Cowan, P. (2006). Teaching Mathematics: A Handbook for Primary and Secondary School Teachers. London: Routledge.

Dalelo, A., T/Mariam, A., \& Kassaye, M.. (2008). The Structure and Content of Secondary School Teacher Education programs: International and National Experiences, Journal of Education for Development, Vol. II, No. II, Addis Ababa. 
Foote, M. [Ed.] (2010). Mathematics Teaching and learning in K-12: Equity and Professional Development. New York: Palgrave Macmillan.

Gates, P. [Ed.] (2001). Issues in Mathematics Teaching. London: RoutledgeFalmer.

Glenda, A. \& Margaret, W. (2009). Effective Pedagogy in Mathematics. Brussels: International Academy of Education.

Jaworski, B. et al [Eds.] (1999). Mathematics Teacher Education: Critical International Perspectives. London: Falmer Press.

Kassa, K. \& Amdemeskel, Y. (2013). Practices and Challenges of Post-Graduate Diploma in Teaching Programme: The Case of Haramaya University, Ethopia. e-reflection journal, Vol. II (IV), P.254-274.

Kessel , C. [Ed.]. (2009). Teaching Teachers Mathematics: Research, Idea, Projects and Evaluation. Berkeley: Mathematical Science Research Institute.

Leikin, R. \& Zazkis, K. [Eds.] (2010). Learning through Teaching Mathematics, Mathematics Teacher Education 5. New York: Springer.

Leu, E. \& Ginsburg, M. (2011). First Principles: Designing Effective Education Program for InService Teacher Professional Development. Educational Quality Improvement Program 1 (EQUIP1). Retrieved from www.equip123.net

MoE (2007). Ethiopian Teachers' Development Program Blue Print. Addis Ababa: Educational Materials Production and Distribution Enterprise.

MoE (2012). Professional Standard for Ethiopian School Teachers. Retrieved from www.edu.gov.et

NCTM (2000). Principles and Standards for School Mathematics. Retrieved from www.nctm.org

Roesken, B. (2011). Hidden Dimensions in the Professional Development of Mathematics Teachers: In-Service Educator for and With Teachers. Rotterdam: Sense Publishers.

Semela, T. (2014) Teacher Preparation in Ethiopia: a Critical Analysis of Reforms, Cambridge Journal of Education, 44:1, 113-145.

Simon, M. (2008). The Challenge of Mathematics Teacher Education in the Area of mathematics Education Reform. In B. Jaworski \& T. Wood (Eds.), The Mathematics Teacher Educator as a Developing professional, 17-29.

Sullivan, P. (2011). Teaching Mathematics: Using Research-Informed Strategies. Camberwell: ACER Press.

Zaslavsky, O \& Sullivan, P. [Eds.] (2011). Constructing Knowledge for Teaching Secondary Mathematics: Tasks to Enhance Prospective and Practicing Teacher Learning. New York: Springer.

Zaslavsky, O. (2008). Meeting the Challenges of Mathematics Teacher Education through Design and Use of Tasks that Facilitate Teacher Learning. In B. Jaworski and T. Wood (eds.), the Mathematics Teacher Educator as a Developing Professional, 93-114. Rotterdam: Sense Publishers. 